Chapter Title: The Challenges of New Work in History and Education about the Holocaust in Poland

Chapter Author(s): JOLANTA AMBROSEWICZ-JACOBS

Book Title: New Directions in the History of the Jews in the Polish Lands

Book Editor(s): Antony Polonsky, Hanna Węgrzynek, Andrzej Żbikowski

Published by: Academic Studies Press. (2018)

Stable URL: https://www.jstor.org/stable/j.ctv7xbrh4.23

JSTOR is a not-for-profit service that helps scholars, researchers, and students discover, use, and build upon a wide range of content in a trusted digital archive. We use information technology and tools to increase productivity and facilitate new forms of scholarship. For more information about JSTOR, please contact support@jstor.org.

Your use of the JSTOR archive indicates your acceptance of the Terms \& Conditions of Use, available at https://about.jstor.org/terms

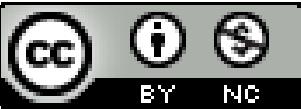

This book is licensed under a Creative Commons Attribution-NonCommercial 4.0 International. To view a copy of this license, visit

http://creativecommons.org/licenses/by-nc/4.0/. Funding is provided by Knowledge Unlatched Open Services. 


\section{The Challenges of New Work in History and Education about the Holocaust in Poland}

\section{JOLANTA AMBROSEWICZ-JACOBS}

$\mathrm{D}$ uring the postwar years through the 1990s, museums and places of remembrance in former death camps in Poland focused mainly on the occupation, the martyrdom of the Polish nation, and patriotic education. During the 1980s, the subject of the Holocaust began to appear more often in scholarly studies, publications, and, gradually, after the fall of communism, in school curricula and displays in museums and places of remembrance. A period of non-remembrance was followed by competition over who had suffered most, reinforced by Polish messianism of romantic lineage, an attitude among Poles that ascribed to the Polish nation moral superiority. ${ }^{1}$ The hypothesis that this led to a competition in suffering, especially in relation to Jews, was put forward by a group of scholars in Warsaw, under the direction of Ireneusz Krzemiński and Aleksandra Jasińska-Kania, who studied the attitudes of Poles toward other nations. The hypothesis was supported by Marcin Kula, Antoni Sułek, Zdzisław Mach, Michał Bilewicz, and Anna Stefaniak. ${ }^{2}$

1 "Opowiadać o ludzkim cierpieniu" [Telling stories of human suffering], Andrzej Franaszek in conversation with Professor Maria Janion, Tygodnik Powszechny, no. 6 (November 2, 2007): 8.

2 See Ireneusz Krzemiński, ed., Czy Polacy sa antysemitami? Wyniki badania sondażowego [Are Poles anti-Semites? Results of a public opinion survey] (Warsaw: Oficyna Naukowa, 1996); Aleksandra Jasińska-Kania, “Zmiany postaw Polaków wobec różnych narodów i państw" [Changes in the attitudes of Poles towards different nations and states], in Bliscy 
This battle for victim status blocks empathy for the suffering of others and prevents the perception of the complexity of Polish attitudes toward Jews during the Holocaust; such complexity is revealed in recent historical scholarship, discussed later in this essay.

A report by the Center for the Future of Museums, under the auspices of the American Alliance (formerly Association) of Museums, titled "Museums and Society 2034," shows the evolution of the role of museums, pointing out factors that have led to changes in their relationship with visitors, and how passive museum narratives have been transformed into interactive ones. ${ }^{3}$ The POLIN Museum of the History of the Polish Jews has the opportunity to change the attitudes of Poles, especially younger ones, toward Jews, and toward the Holocaust and its memory, on the basis of careful planning and systematically applied research. The observations in this essay on the subject of the museum refer exclusively to the Holocaust Gallery and, in light of the writer's own research, to teaching about the Holocaust in Poland and the attitudes of young Poles. It should be pointed out that these observations, some in the form of suggestions, are less important than visitors' reactions to the gallery and the effects of visiting the exhibit. I imagine that for a great many young Poles, who cannot easily get to museums and places of remembrance connected with the Holocaust, ${ }^{4}$ the Holocaust Gallery might be the only source of education on this subject, in addition to or in place of teaching in school. Indeed, many schools plan trips to Warsaw.

i dalecy: studia nad postawami wobec innych narodów, ras i grup etnicznych [Near and far; studies on attitudes towards other nations, races and ethnic groups], ed. Aleksandra JasińskaKania, vol. 2 (Warsaw: Uniwersytet Warszawski, 1992), 219-46; Marcin Kula, Nośniki pamięci historycznej [The carriers of historical memory] (Warsaw: Wydawnictwo DiG, 2002); Antoni Sułek, "Zwykli Polacy patrzą na Żydów" [The Ordinary Poles look at the Jews], Nauka 1 (2010): 7-23, http://www.pan.poznan.pl/nauki/N_110_01_Sulek.pdf; Zdzisław Mach, "The Holocaust in Public Memory and Collective Identity of Poles," in Fact and Lies in the Common Knowledge on the Holocaust. Conference Materials, 2005.11.17, ed. Daria Nałęcz and Mariusz Edgaro (Warsaw: Oficyna Wydawnicza "Aspra-JR," 2006), 99-103; Michał Bilewicz and Anna Stefaniak, "Can a Victim Be Responsible? Anti-Semitic Consequences of Victimhood-based Identity and Competitive Victimhood in Poland," in Responsibility: A Crossdisciplinary Perspective, ed. B. Bokus (Warsaw: Studio Leksem, 2013), 69-77.

3 Museums and Society 2034: Trends and Potential Futures, Center for the Future of Museums (Washington, DC, 2008), http://www.aam-us.org/docs/center-for-the-future-of-museums/ museumssociety2034.pdf.

4 Part of the problem is true not only in Poland and was discussed in a report based on studies by the Fundamental Rights Agency (FRA) in 2010. Attention should also be drawn to the lack of funds, despite a declaration by EU ministers of education and culture, to the need for parents to pay for visits, logistical problems, and lack of time during the school year. 
Special attention should be devoted to teachers, partly because of the reform introduced by the minister of education in December 2008 that excluded the subject of the Holocaust from the secondary school history syllabus, while leaving it in the social studies and Polish literature syllabi. This change was prompted by the desire for an in-depth study of recent history once over the course of a school education, instead of relegating it to two more superficial topics at the end of the third form in academic secondary schools and then in postsecondary schools, where time was limited because of final examinations. Until systematic changes are made in this reform, it is clearly necessary to influence the group most affected by the 2008 reform-secondary school history teachers and postsecondary teachers of social studies and Polish. Certainly, despite the influence of the electronic media and peer groups, the attitudes of young people toward the Holocaust do depend on their teachers' attitudes, knowledge, competence, and teaching skills. Before visiting museums and places of remembrance, young people should be prepared in school by their teachers.

There is no one definition of the Holocaust or of education on the Holocaust agreed upon by state and nongovernmental institutions. Almost every significant Holocaust museum in the world adopts a slightly different definition-these are not in conflict but differ in their perspective, extent, and detail. Education about the Holocaust under the project of the European Union's Fundamental Rights Agency (FRA) has been defined as "education that takes the discrimination, persecution and destruction of the Jews by the National Socialist regime as its focus, but also includes Nazi crimes against other victim groups, both for the purpose of deeper understanding and contextualization of the Holocaust and out of a desire to acknowledge and commemorate the suffering of numerous non-Jewish victims of the Nazi era."5

The Holocaust Gallery at the POLIN Museum rightly focuses on the fate of the Jews condemned to death, mainly on Jews from Warsaw, so its creators have adopted a different educational perspective on the history of the Holocaust from the FRA. Perhaps the UNESCO Chair for Holocaust Education at the Jagiellonian Museum, in cooperation with the museum, could examine the difference in impact between teaching about the Holocaust in the context of other victims and teaching focused exclusively on the fate of the Jews not

5 "Discover the Past for the Future: The Role of Historical Sites and Museums in Holocaust Education and Human Rights Education in the EU," European Union Agency for Fundamental Rights, 2011, 9, http://fra.europa.eu/sites/default/files/fra uploads/1791-FRA-2011-Holocaust-Education-Main-report_EN.pdf. 
only in terms of assimilating information but also in terms of understanding historical facts and changing attitudes. Describing the Holocaust Museum in Washington, DC, Anna Ziębińska-Witek uses the expression "the concept of imagined death." 6 Personalizing the commentary in the Holocaust Gallery in the POLIN Museum, the gallery's small size (a simulacrum ${ }^{7}$ of overcrowding in the ghetto), and the idea of the footbridge over Chłodna Street, all serve to stir the imagination and arouse empathy with the victims. Only research will show whether the exhibit's extremely effective presentation is also a useful pedagogical strategy for changing visitors' perceptions.

The variety of programs and projects on the Holocaust in Poland is rarely accompanied by reflection on the aims of teaching, program content, methodology, and evaluating their results. As Tomasz Kranz correctly observes in writing about museums located in former camps - although his remarks apply to all museums - visitors' needs and expectations require assessment:

Recognizing and evaluating [its motivations, expectations and needs] is a key condition for improving communication with the museumgoing public and, at the same time, making it possible for visitors better to absorb recent scholarship... The experiences of traditional museums are proof of the need to conduct sociological studies on these issues. ${ }^{8}$

There is a lack, and not only in Poland, of constructive discussion about the following key questions: What are the aims of education on the Holocaust? Should teaching about the Holocaust be based on historical research and stress context, or it be conducted through the prism of civic engagement? What are the limits in framing the issues of Holocaust history in terms of investigations into the nature of society? What dangers are inherent in universalist approaches? What is the value of comparativist approaches?

Since the mid-1990s, I have been engaged in research into teaching about the Holocaust in schools and elsewhere (including places of remembrance).

6 Anna Ziębińska-Witek, "Estetyki reprezentacji śmierci w ekspozycjach historycznych" [The aesthetic of representing death in historical displays at museums], in Obóz-muzeum. Trauma we wspótczesnym wystawiennictwie [Camp-museum. Trauma in contemporary display], ed. Małgorzata Fabiszak and Marcin Owsiński (Kraków: Towarzystwo Autorów i Wydawców Prac Naukowych "Universitas," 2013), 39.

7 J. Baudrillard's phrase in Ziębińska-Witek, “Estetyki reprezentacji,” 38.

8 Tomasz Kranz, "Muzea martyrologiczne jako przestrzenie pamięci i edukacji” [Martyrological museums as spaces of memory and education], in Obóz-muzeum, 59. 
One aim of my research has been to analyze attitudes toward Jews and the Holocaust in order to make possible the development of effective teaching strategies, especially where ethnocentrism, anti-Semitism, entrenched opinions, and, indeed, outright lies about Auschwitz are present in the minds of schoolchildren. My own research conducted in 1998 showed that not every educational project produces the desired positive effect in terms of attitudes toward Jews. In addition to a survey in 2008, between 2008 and 2010 I used quantitative and qualitative methods in my research into memory of the Holocaust. ${ }^{9}$ This research focused, above all, on postmemory (Marianne Hirsch's term, now a key term in liberal arts research): memory is not "living" memory based on direct personal experience, but is inherited or borrowed. She also raises the question not only of how memory should be transmitted, but also of who can or should be a "guardian" of a traumatic past with which we have no personal or direct contact, but toward which we are not indifferent.

Post-memory, like memory, is not monolithic; it is full of zigzags, blank pages, oblique remarks, linguistic codes, and ubiquitous taboos. Historical facts are permanent; however, representations of them can vary, and even conflict with one another. The history of the Holocaust on Polish soil is remembered or recreated differently by Jews and by Poles. Jews remember Poles' attitudes toward Jews - the general indifference, the courage of a few, the fear of denunciations and murder. The Poles want above all to remember the courage of their ancestors and of the rescuers. They do not want to accept aspects of local memory and new research in history which show that the rescuers' attitudes were not common and that in towns under German occupation denunciation and blackmail were widespread, as was the hunting of Jews who had escaped from transports and were trying to survive in dugouts in the countryside.

Unfortunately, not enough research has been done to accompany theoretical thinking about postmemory. Postmemory is not about one's own memories, but about often traumatic memories felt by earlier generations. Since we ourselves do not return to our memories if they cause us pain, subsequent

9 The research included a nationwide survey ( $\mathrm{N}=1000,17-18$ year-olds), a focus group with eight teachers/experts (set up by the CEM Market and Public Opinion Research Institute in Kraków on April 17, 2009), an evaluation of written curricula into which the study of Jewish history and culture, as well as memory of the Holocaust, had been introduced (control group $\mathrm{N}=1110$, school pupils above primary school, as well as students in tertiary education), observation of selected programs: Tykocin/Treblinka (23 pupils), Kielce (124), Lublin (11), Bodzentyn/Starachowice (54), Warsaw (15), and one-on-one interviews with teachers and NGO leaders (44) and pupils (61). 
generations do. The return can be therapeutic; however, this is not the rule. Limits of access to memory can be caused not only by self-censorship, but also by deliberate actions by state agencies. Deformation of memory is not solely a function of totalitarian systems, but can become a strategy of everyone armed with a laudable past who turns their backs on examples of shame, seeking in the past encouragement and/or compensation for real failures, or simply a lack of success. The myth of the honorable, heroic Polish past, particularly during the Second World War, is tenacious and ingrained, prevents a general group acceptance of the facts that undermine this myth.

Nevertheless, my own research demonstrates that "experimental" teaching about the Holocaust practiced by creative teachers and NGO activists that goes beyond the basic syllabus makes sense and produces statistically quantifiable effects, although they are smaller than those involved in teaching about the Holocaust expected. A greater percentage of respondents from experimental group E, when compared to control group $\mathrm{K}$ representing schoolchildren who had completed primary school, knew in 2008 what percentage of Poland's prewar population consisted of Jews (E, 18 percent; K, 5 percent). The average attitude on a scale of attitudes toward Jews was higher in group E (3.5) than in group $\mathrm{K}$ (3.2). A greater percentage of pupils from group $\mathrm{E}$ than in control group K defined the Holocaust as the Destruction of the Jews (E, 59 percent; $\mathrm{K}, 33$ percent). A greater percentage of pupils in this group also correctly identified the number of Jewish victims of the Second World War (E, 34 percent; K, 14 percent).

From the point of view of a scholar of comparativist attitudes toward the Holocaust, the question as to whether the Holocaust Gallery in the POLIN Museum will effect changes in viewing Poland's past in relationship to the Holocaust, especially among the younger generation of Poles, seems appropriate. Will it cope with the many years of absence of memory, the silences, the warping, the disfiguring, and the ubiquitous taboo on discussing individual and group collaboration on the part of Poles with the German occupier? Some Poles-and everyone was a victim during the time of the occupation's terror tactics - killed other victims, in other words, Jews in hiding. This historical fact represents a challenge for Poles' collective identity and often produces defensive reactions, including secondary anti-Semitism. How can we make this fact part of the educational process, given how often information contrary to our positive self-image is rejected, while maligned people are devalued and demonized?

Polish witnesses to the Holocaust manifest a memory that has been muffled, suppressed by a sense of guilt at the behavior of some members of their 
own national group and by the memory of their own victims. This memory does not include Polish Jews within the framework of the shared category of citizenship. Additionally, communist ideology denied Polish Jews the right to be present in the history of Poland. Postwar mourning embraced the Polish nation without its Jewish fellow citizens. In the studies mentioned above, nearly one-third of those surveyed felt that it was better that Poland now had fewer Jews than before the war. Among the remainder, the dominant opinion was that it was neither good nor bad (41 percent of respondents). One in four pupils had no opinion. In the postwar imagined community, ${ }^{10}$ by now covering several generations, there is an absence of Polish Jews, outside the islands of memory created from the mid-1980s by academic institutions and NGOs, as well as local historians or involved educators.

If an historical narrative covering Polish-Jewish relations and the Holocaust began slowly to appear in transmitters of Polish memory, such as in post-1989 textbooks, this process was not accompanied by a parallel appearance of the Holocaust in ethnic Poles' collective group memory. It would be unfair to ignore the great many educational projects produced by historical museums, places of remembrance, or state institutions and NGOs, but it is too soon to speak of a community of memory, or of a common historical narrative of the Holocaust within Polish civil society. The POLIN Museum has an opportunity to change the way in which Jews are perceived and bring them into civil society.

In my own research conducted in 2008, pupils were asked an open question: "What does the term 'Holocaust' mean?" A significant part of them failed to reply to the question or replied that they did not know (39 percent). Only one in three pupils identified the "Holocaust" as a term referring to the destruction of the Jews; 12 percent understood it as destruction of people in general, or of minorities in general. Over half the pupils responded that they did not know how many Jews had died during the Second World War. Barely 14 percent of those surveyed gave the correct number, and this figure leads us to speculate that the Holocaust is treated superficially in Polish schools, without deeper thought on the essence and extent of the crime. Antoni Sulek ascribes the fact that in 2011, a total of 41 percent of pupils aged fifteen through nineteen had not heard about

10 Benedict Anderson's phrase. See Benedict Anderson, Imagined Communities: Reflections on the Origin and Spread of Nationalism, rev. ed. (London: Verso, 1991). 
Jedwabne (18 percent in 2002) not to a lack or a rejection of memory, but to a failure to absorb the facts. ${ }^{11}$

It is not impossible that this attitude toward Jews is, to some degree, the result of the perception of the Polish Jew as the Other, about which Alina Cała wrote in the 1990s, despite nearly a thousand years of common history. ${ }^{12}$ Over the course of that common history, the Catholic church nurtured attitudes of mistrust and/or hostility toward Jews. "Father Franciszek B.," recalled Michał Głowiński, ${ }^{13}$ "invoking the authority of the Church and the principles of faith taught that all Jews were responsible for the crucifixion, all without exception, irrespective of where and when they lived, responsible always and everywhere and that nothing could ever change that."

Only research will show what will and will not "register" with Polish schoolchildren visiting the Holocaust Gallery. To Aleida Assmann's question posed during a conference in Vienna in December 2014, ${ }^{14}$ "Is the Holocaust still seen as a German project?” the gallery replies that it is. A large photograph of the conference hall in Wannsee, as well as photographs of participants at the conference-high-ranking officials of the Third Reich-leaves no doubt. The participation in the Holocaust of "helpers" of the Third Reich is also referred to; this essay will have more to say on the matter.

In the most recent Polish school textbooks published after the 2008 reform, the history of the Holocaust was presented in line with international scholarly standards, while the subjects of Poles' attitudes toward the Holocaust or the context of "the Righteous" raise serious concerns. ${ }^{15}$ The newest research in history, above all the achievements of scholars at the Centrum Badań nad

11 Antoni Sułek, "Pamięć Polaków o zbrodni w Jedwabnem" [The crime in Jedwabne as remembered by Poles], Nauka 3 (2011): 39-49, http://www.pan.poznan.pl/nauki/N_311_02_ Sulek.pdf.

12 Alina Cała, The Image of the Jew in Polish Folk Culture (Jerusalem: Magnes Press, 1995), 220.

13 Michał Głowiński, Czarne sezony [Black seasons] (Warsaw: Wydawnctwo Literackie, 1999), 148.

14 Seminar, "Remembrance of the Holocaust and Nazi Crimes in Post-1989 Europe: Reflecting on Competition and Conflict in European Memory International Workshop," Austrian Academy of Sciences, European Network Remembrance and Solidarity, Konstanz University, Vienna, December 15-16, 2014.

15 Jolanta Ambrosewicz-Jacobs and Robert Szuchta, "The Intricacies of Education about the Holocaust in Poland: Ten Years after the Jedwabne Debate, What Can Polish School Students Learn about the Holocaust in History Classes?," Intercultural Education 25, no. 4 (July 2014): 283-99. 
Zagładą Żydów (Polish Center for Holocaust Research), ${ }^{16}$ are not widely reflected in the educational process and are mentioned solely by individual educator-enthusiasts. Likewise, as Sławomir Kapralski has pointed out, ${ }^{17}$ in the exhibit in the renovated synagogue in Dąbrowa Tarnowska there is no mention at all of Jan Grabowski's research presented in the book Jugenjagd: Polowanie na Żydów 1942-1945, ${ }^{18}$ which deals with the district in which this town is located. In many European countries, there has arisen a divergence between history and memory of the Holocaust. In most but not all of them, ${ }^{19}$ the history of the Holocaust, contrary to the latest research trends, passes over in silence the behavior of their fellow citizens toward the Jews. Historical scholarship does not penetrate public, collective memory since one of the transmitters influencing the processes of postmemory of the Holocaust, namely education, makes a large detour around the latest research. Thus, debates on Polish-Jewish relations at the time of the Holocaust as well as research in the field of education indicate that there is a gap between scholarly research and education. The

16 The most significant publications are Barbara Engelking, "... szanowny panie gistapo". Donosy do wtadz niemieckich $w$ Warszawie i okolicach w latach 1940-1941 ["Dear Mr Gistapo." Denunciations to the German authorities in Warsaw and the surrounding area in the years 1940-1941] (Warsaw: Wydawnictwo IFiS PAN, 2003); Jan Grabowski, "Ja tego Żyda znam!" Szantażowanie Żydów w Warszawie 1939-1943 [“I know this Jew!” Blackmailing Jews in Warsaw 1939-1943] (Warsaw: Wydawnictwo IFiS PAN, 2004); Barbara Engelking and Dariusz Libionka, Żydzi w powstańczej Warszawie [Jews in Warsaw during the 1944 uprising] (Warsaw: Stowarzyszenie Centrum Badań nad Zagładą Żydów, 2009); Tadeusz Markiel and Alina Skibińska, "Jakie to ma znaczenie, czy zrobili to z chciwości?" Zagtada domu Trynczerów ["What difference does it make if they did it out of greed?" The murder of the Trynczer family] (Warsaw: Stowarzyszenie Centrum Badań nad Zagładą Żydów, 2011); Barbara Engelking, "Jest taki piękny stoneczny dzień. .. Losy Żydów szukających ratunku na wsi polskiej 1942-1945 ["It was such a beautiful sunny day ..." The fate of Jews seeking shelter in the Polish countryside 1942-1945] (Warsaw: Stowarzyszenie Centrum Badań nad Zagładą Żydów, 2011); Jan Grabowski, Judenjagd. Polowanie na Żydów 1942-1945. Studium dziejów pewnego powiatu (Warsaw: Stowarzyszenie Centrum Badań nad Zagładą Żydów, 2011), English edition: Hunt for the Jews. Betrayal and Murder in German-Occupied Poland (Bloomington: Indiana University Press, 2013); Zarys krajobrazu. Wieś polska wobec zagłady Żydów 1942-1945 [A sketch of the countryside. Polish village in the face of the mass murder of the Jews], ed. Barbara Engelking and Jan Grabowski and introduction by Krzysztof Persak (Warsaw: Stowarzyszenie Centrum Badań nad Zagładą Żydów, 2011); Dariusz Libionka and Laurence Weinbaum, Bohaterowie, hochsztaplerzy, opisywacze. Wokót Żydowskiego Zwiazku Wojskowego [Heroes, swindlers and graphomaniacs. On the Jewish Military Union] (Warsaw: Stowarzyszenie Centrum Badań nad Zagładą Żydów, 2011).

17 A lecture at the Jewish Cultural Centre in Kraków, December 2014.

18 Grabowski, Judenjagd. Polowanie na Żydów.

19 In Scandinavian countries, the "black" history of the Holocaust, including collaboration, is mentioned in school textbooks (e.g., in Norway). 
exceptions are committed teachers, including many graduates of the last ten years of the Center for Holocaust Studies of the Jagiellonian University and its International Summer Schools for the Study of the Holocaust. ${ }^{20}$ Research conducted among young people in Poland in 2008 indicates that knowledge and understanding of the Holocaust in classes conducted by committed teachers who deepen their own education while working in a school are greater than in a representative sample.

Information on Poles' multiple attitudes toward Jews during the Second World War is available in the Holocaust Gallery and is visible thanks to the large size of the displays. However, accounts of cases of denunciation, murder, and death of Jews in hiding at the hands of Poles, as well as those of rescuers, are placed very low, so low that one has to bend down to read them. The intention of the exhibit's creators was to use space to convey how much the Jews in hiding suffered, how hard it was for them. But, paradoxically, it is also difficult to get information about the individual fates of those in hiding. The location of this information forces one to adopt such a contorted posture that many people may well pass through the gallery sparing themselves the difficulty of obtaining the information and thus not learning about the fate of Jews handed over to death by Poles. Ironically, the scholars (Barbara Engelking and Jacek Leociak) who placed this information down "beneath the surface" are those who are bringing the dark history of Polish attitudes during the Holocaust "to the surface" through their research and publications. But in the museum, the dark history can continue to lie undiscovered, pushed aside, rejected, and "unregistered."

The time devoted to absorbing this information is key. A pupil in Robert Szuchta's class at Warsaw High School No. LXIV stated that the important thing was that "You don't have to rush . . . there's no hurry up, hurry up, no time to stop here, let's go, let's move on. There's a chance to feel it. Not just learn about it, but feel it." Will pupils visiting the museum have enough time to "stop here" in the Holocaust Gallery to learn the fate of the Warsaw Jews condemned to die, ${ }^{21}$ for the commentary is principally directed at them? Will they have an opportunity not just to learn, but also to feel? This depends to a

20 The summer schools were organized jointly with the Chair for Holocaust Studies at the Institute of European Studies, Jagiellonian University, the Illinois Holocaust Museum and Education Center in Skokie, United States, and Yad Vashem, in cooperation with Polish institutions and NGOs in Kraków and Oświęcim.

21 The Holocaust Gallery focuses on the site of the POLIN Museum. A similar idea (commentary on one former Nazi death camp) motivated the creators of the exhibit at the MuseumMemorial Site in Bełżec. 
great extent on the educators at the Education Center and the guides at the POLIN Museum, and also on the teachers, who will need to prepare young people before their visit to the museum and then discuss the visit afterwards. Also, young people demonstrate a need for empathy during the process of learning about the Holocaust. There is no agreement whether cognitive rather than affective components ${ }^{22}$ are more effective in education. It may be that it is precisely empathy that will allow us to see Jews, both in the past and today, as part of the community of fellow citizens.

Tomasz Kranz, Robert Szuchta, Piotr Trojański, and other experts, as well as working teachers, ${ }^{23}$ have written frequently about the theoretical, methodological, and logistical problems of education about the Holocaust. Apart from a lack of theoretical underpinnings and methodology, as well as the imprecision of the words "education about the Holocaust," on which, above all, Tomasz Kranz, director of the Majdanek Museum, has written, in my view

22 The Kraków-based sociologist Marek Kucia suggests an emphasis on strengthening the cognitive over the affective components in Holocaust education. See Marek Kucia, "Optymistyczne dane-niepokojące pytania—radykalne wnioski" (Optimistic dataunsettling questions—radical conclusions)," in Auschwitz i Holokaust. Dylematy i wyzwania polskiej edukacji [Auschwitz and the Holocaust. Dilemmas and challenges faced by Polish education], ed. Piotr Trojański (Oświęcim: Państwowe Muzeum Auschwitz-Birkenau, 2008), 35-44. Trojański suggests in turn that we shift the center of gravity from transmitting information to forming attitudes as well as adding axiological ideas: he feels that education about the Holocaust ought to lay greater emphasis on prevention by including a psychological prism, with the aim of understanding the processes leading to genocide. See Piotr Trojański, "Edukacja o Holokauście w Polsce. Próba krytycznego bilansu" [Education on the Holocaust in Poland. An attempt to strike a critical balance], in Edukacja muzealna w Polsce. Aspekty, konteksty, ujęcia [Museum education in Poland. Aspects, contexts, undertakings], ed. Wiesław Wysok and Andrzej Stępnik (Lublin: Państwowe Muzeum na Majdanku, 2013), 129-50.

23 Tomasz Kranz, "Pedagogika pamięci jako forma edukacji muzealnej" [The pedagogy of memory as a form of museum education], in Wizyty edukacyjne w Państwowym Muzeum na Majdanku. Poradnik dla nauczycieli [Educational visits to the State Museum in Majdanek. A guidebook for teachers], ed. Tomasz Kranz (Lublin: Państwowe Muzeum na Majdanku 2012), 11-25; Tomasz Kranz, "Posłowie," [Afterword] in Edukacja Muzealna w Polsce. Aspekty, konteksty, ujęcia; Jacek Chrobaczyński and Piotr Trojański, eds., Holokaust_lekcja historii. Zagtada Żydów w edukacji szkolnej [The Holocaust-a lesson in history. The genocide of Jews in school teaching] (Kraków: Wydawnictwo Nauk. Akademii Pedagogicznej, 2004); Jak uczyć o Auschwitz i Holokauście. Materialy dydaktyczne dla nauczycieli [How does one teach about Auschwitz and the Holocaust. Didactic materials for teachers], texts selected and ed. Jolanta Ambrosewicz-Jacobs, Krystyna Oleksy, and Piotr Trojański (Oświęcim: Międzynarodowe Centrum Edukacji o Auschwitz i Holokauście Państwowego Muzeum Auschwitz-Birkenau, 2007); Auschwitz i Holokaust. Dylematy i wyzwania polskiej edukacji, ed. Piotr Trojański (Oświęcim: Państwowe Muzeum Auschwitz-Birkenau, 2008). 
teaching on the subject of the Holocaust in Poland has special limitations. What is important in teaching about the Holocaust in Poland? What is important is that the history of the Jews before the Holocaust, the Holocaust, and the renewal of Jewish life after the war be assimilated, "registered" as "everyone's" work, as the history of fellow citizens. A prerequisite is to abandon perceiving the nation and group identity in terms of ethnic categories. In Poland, this is a long and difficult process that requires the awareness of teachers and of other social agents of education, as well as bold strategic approaches to embrace the historical narrative in textbooks, as well as to encourage teachers to experiment in their teaching. According to contemporary experts Zehavit Gross and Doyle Stevick, ${ }^{24}$ experimental teaching in the area under discussion is more effective within the framework of civic education than within history teaching. Scholars also suggest an increased emphasis on experimental education as opposed to education based on sedentary activities in school.

Museum discussions and visits to places of remembrance as well as projects belong to experimental education. Leaders in this type of education that aims at creating islands of memory about Polish Jews, such as Piotr Krawczyk, assert that "we owe the Polish inhabitants of Chmielnik something." ${ }^{25}$ This historian from Chmielnik-like Artur Franczak from Nowy Sącz, Joanna Zętar from the Brama Grodzka NN Theater Center in Lublin, and Adam Musiał, a teacher from Kraków - is aware that many small Polish towns owe their existence to Jews and that Jews were co-founders of many of them. But in addition to a great many islands of memory in Poland, there are also islands of non-memory, lieux d'oubli (places of forgetfulness), ${ }^{26}$ such as Izbica, ${ }^{27}$ where there is no mention of the town's prewar Jewish inhabitants.

The report of the Center for the Future of Museums, "Museums and Society 2034," referred to at the start of this essay, speaks of museums' potential to inspire action within local communities through causative narratives.

24 Zehavit Gross and Doyle Stevick, eds., As the Witnesses Fall Silent: 21st Century Holocaust Education in Curriculum, Policy and Practice (Cham: Springer International Publishing, 2015).

25 A response during a panel discussion at the 10th International Summer School on Teaching about the Holocaust in July 2015 at the Center for Holocaust Studies at the Jagiellonian University.

26 A phrase used by Yoseph Haim Yerushalmi referring to concepts of "lieux de mémoire" [places of memory] of Pierre Nora. See Yoseph Haim Yerushalmi, ed., Usages de l'oubli [The uses of forgetting] (Paris: Le Seuil, 1988); Pierre Nora, "Between Memory and History: Les Lieux de Mémoire," Representations 26 (Spring 1989): 7-24.

27 Information provided by Robert Szuchta in July 2015. 
Referring to this report, experts of the Małopolski Institute of Culture write openly: "The Museum creates new needs and does not just respond to its visitors' expectations, although it attaches great importance to them." 28

The POLIN Museum has an opportunity to make more widely known the new historiographical research in Poland, which, unfortunately, is not fully reflected in the educational process. I have high hopes that a visit to the museum will encourage many teachers and pupils throughout Poland to look for traces of a Jewish past in the towns from which they will have come to Warsaw, and will allow them to feel the emptiness that the Holocaust has left. And this feeling of emptiness will grow into a need to take care of memory of the Jews, those from Poland and those shipped in from the whole of Europe to be murdered on our soil. Polish group identity badly needs such guardians of memory.

28 Joanna Hajduk, Łucja Piekarska-Duraj, Piotr Idziak, and Sebastian Wacięga, Lokalne muzeum $w$ globalnym świecie — poradnik praktyczny [The local museum in a global world-a practical guide] (Kraków: Małopolski Instytut Kultury, 2013), cover. See also 153-57, http://esklep.mik.krakow.pl/ebooks/lokalne_muzeum_w_globalnym_swiecie.pdf. 